\title{
DEVELOPING “BEBERAN" GAME BOARD AS AN INNOVATIVE MEDIA TO IMPROVE STUDENTS' SPEAKING SKILLS OF PRE-SERVICE TEACHERS OF ISLAMIC ELEMENTARY EDUCATION
}

\author{
Herman Khunaivi ${ }^{1}$
}

\author{
STAI Al-Anwar Sarang, Rembang, Indonesia ${ }^{1}$ \\ Email: hermankhunaivi@ staialanwar.ac.id ${ }^{1}$
}

DOI: 10.14421/al-bidayah.v13i1.314

\begin{abstract}
This study aimed to develop a "Beberan" game board as a practical, efficient, and innovative media to improve students' speaking skills. It was carried out using the research and development method by applying Borg, Gall, and Sugiyono theories. Furthermore, it involved seven steps: analysis, designing product, preliminary test, experts' judgments, product revisions, field test, and final product of media. A total of 30 students of the pre-service teacher study program of the Islamic elementary education, Al-Anwar Islamic College, were the subjects. The instruments used were observation, interview, and test. Based on the data obtained, the results showed that developing the "Beberan" game board as an innovative media improved students' speaking skills at the beginner level. This improvement was observed in the result obtained from the pre-test and post-test scores, which increased from 67.867 to 72.133 .
\end{abstract}

\section{Keywords: "beberan" game board; innovative media; islamic elementary education; pre-service speaking skill}

\section{INTRODUCTION}

English is a general language taught at various levels in almost every school in Indonesia. This phenomenon happened because English has different characteristics from other fields of study due to its function as a means of communication. Furthermore, suggestions have that learning English involves being conversant with the rules guiding vocabulary and grammar as a means of knowledge and its application in communication. Students should therefore be able to use words and phrases very smoothly without much conscious thought. For example, the more students participate, activate, and use English as a spoken language in class, the higher the tendency to store various elements of the language in their brains. Furthermore, classroom participation has received much attention as an important component in student learning and academic success ${ }^{1}$. Therefore, students gradually become autonomous language users ${ }^{2}$.

${ }^{1}$ Jennifer C. Theriault, "Exploring College Students' Classroom Participation: A Case Study of A Developmental Literacy Classroom," Journal of College Reading and Learning 49, no. 3 (September 2, 2019): 206-22, https://doi.org/10.1080/10790195.2019.1638219.

2 Jeremy Harmer, How to Teach English (Oxford: Pearson Education Limited, 2007). 
One of the problems generally associated with language learning is speaking or the ability to speak English. According to Kosar and Bedir, the core of language learning is speaking. One of the assumptions of language learning in society is that success was discovered by accomplishing acquisition in speaking ${ }^{3}$.

Leong and Ahmadi stated that the foremost skill for the effectiveness of communication is speaking. This statement means that without any form of speech, communication will not exist ${ }^{4}$. However, the problem that often arises is that a few students can speak, while those at the university level in rural areas are in the upper level. There are many reasons behind these problems, with the most common being that students are often not fluent in speaking English. The cause was they are less accustomed to using the English language as a means of communication in a day, as students often seem to think in advance what to talk about. The learners are still reluctant to take an active role in classroom interactional tasks ${ }^{5}$. Learning in the classroom is to put into practice what was learned in everyday life. In that case, speaking fluently is a way of best using the known content and knowledge ${ }^{6}$.

Similarly, Caicedo concluded that English was not viewed as an important asset based on the classroom observations, and this perception resulted in low students' participation in English class ${ }^{7}$. Indeed, spoken English is one of the most important things which assist learners in proper communication. Therefore, language learning should be applied in communication, ${ }^{8}$ and the students should possess the skill required to communicate in their lives ${ }^{9}$. Speaking is one of the compulsory subjects at university,

${ }^{3}$ G Koşar and Hasan Bedir, "Strategies-Based Instruction: A Means Of Improving Adult EFL Learners' Speaking Skills," International Journal of Language Academy 2, no. 3 (2014): 12-26, http://oaji.net/articles/2014/505-1411382239.pdf.

${ }^{4}$ Leong Lai Mei and Ahmadi Seyedeh Masoumeh, “An Analysis of Factors Influencing Learners' English Speaking Skill” 2, no. 1 (January 1, 2017): 34-41, https://www.sid.ir/en/journal/ViewPaper.aspx?ID=520992.

5 ohd. Yusof Abdullah, Noor Rahamah Abu Bakar, and Maizatul Haizan Mahbob, "Student's Participation In Classroom:What Motivates Them To Speak Up?," Procedia - Social and Behavioral Sciences, The World Conference on Design, Arts and Education (DAE-2012), May 1-3 2012, Antalya, Turkey, 51 (January 1, 2012): 516-22, https://doi.org/10.1016/j.sbspro.2012.08.199.

${ }^{6}$ Leong and Ahmadi, “An Analysis of Factors Influencing Learners'english Speaking Skill.”

${ }^{7}$ Jefferson Caicedo, "Teacher Activities and Adolescent Students' Participation in a Colombian EFL Classroom," Profile Issues in Teachers` Professional Development 17, no. 2 (July 2015): 149-63, https://doi.org/10.15446/profile.v17n2.48091.

8 Ministry of Education, “Special Guidelines Competency-Based Curriculum Development Syllabus English' (Curriculum Development Syllabus English)” (Minister of Education, 2004).

${ }^{9}$ Kunandar, Guru Profesional Implementasi Kurikulum Tingkat Satuan Pendidikan (KTSP) Dan Sukses Dalam Sertifikasi Guru (Jakarta: Rajawali Pers, 2014). 
which becomes easier provided that students are allowed to speak every time on many occasions. Furthermore, students focus on obtaining things done and creating a warm relationship in their environment.

The government of Indonesia has drawn up English as a foreign language that every student should master. This skill should be mastered at the junior and senior high school level and the university level. Especially, those with plans of becoming full-time teachers at school.

Due to the function of the English language as a tool in communication, it has different characteristics from sciences and social sciences. This language identifies that learning English once again entails being conversant with the rules guiding vocabulary and grammar as it is carried out in the classroom but should also be used as a daily means of communication. This explanation means that those to study English should use words and phrases very smoothly and fluently. Bahadorfar and Omidvar stated that one of the reasons why English learners should speak is because it is presently used as an important part of language learning and teaching for ESL (English as a Second Language) or EFL (English as a Foreign Language). Furthermore, Abebe and Deneke described that the EFL setting is a 'frustrating place'. This finding was in response to students' reticence and reluctance to interact and speak in EFL classrooms ${ }^{10}$. All language learners must master speaking because proficiency in speaking is one of the instruments used in evaluating whether they are second or foreign language acquisition learners ${ }^{11}$.

According to Richards, there are some functions of speaking in interaction. Firstly, it establishes and maintains social relationships among society. Secondly, it acts as a transactional device that focuses on exchanging information. In addition, the aim of speaking can be for interaction, transaction, and performance ${ }^{12}$. Good speaking activities can and should be extremely engaging for the students ${ }^{13}$. Some points should be

10 Dawit Tesfaye Abebe and D Deneke, "Causes Of Students' Limited Participation In EFL Classroom: Ethiopian Public Universities In Focus," International Journal of Educational Research and Technology 6, no. 1 (2015): 74-89, http://soeagra.com/ijert/ijertmarch2015/8.pdf.

11 Maryam Bahadorfar and Reza Omidvar, "Technology In Teaching Speaking Skill. Research Scholar, Department of Linguistics, KIKS, University of Mysore, Mysore (India)," Acme International

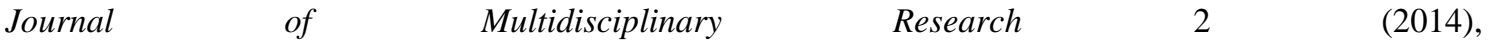
https://www.researchgate.net/publication/315790125_TECHNOLOGY_IN_TEACHING_SPEAKING_S KILL

12 Jack Croft Richards, Teaching Listening And Speaking, (Cambridge: Cambridge University Press, 2008).

${ }^{13}$ Harmer, How to Teach English. 
emphasized in teaching speaking. According to Nunan, five principles have to be considered in teaching speaking, which include 1) second language and foreign-language learning context, 2) providing opportunities to talk, 3) fluency and accuracy, 4) planning for speaking tasks, and 5) classroom activities design ${ }^{14}$. Meanwhile, Harmer states that there are six principles of teaching speaking, which include 1) assist students to overcome their initial reluctance to speak, be encouraging, provide opportunity, start from something simple, 2) asking students to talk at their will, 3) asking students to talk about what can discuss, 4) incorporating the speech acts in teaching speaking, 5) combining speaking with listening and reading, 6) and providing appropriate feedback ${ }^{15}$.

There are many studies in teaching English. One of which is media use especially in teaching speaking. This argumentation was used because it is believed that teaching speaking through media is a good way to ensure that students easily follow the lessons. In speaking classes, students need to have a certain source that aids the evaluation of their performances ${ }^{16}$. Some schools, especially in rural areas, have proved that the implementation of English as a foreign language learning is still passive and teachercentered. This phenomenon tends to make learning English theory seem like language itself.

Consequently, the students have little opportunity to participate besides having self-reflection. Meanwhile, in speaking, self-reflection is very important, being that its major aim is to allow students to evaluate their speaking performances ${ }^{17}$. It is believed that carrying out self-reflections in the students' efforts to develop their speaking skills was productive in that they had the opportunity to reflect on what they had experienced and plan their learning strategies ${ }^{18}$. Therefore, providing students with the opportunity to obtain hands-on knowledge, experience, and practice in developing their intercultural

${ }^{14}$ Caroline Linse, Practical English Language Teaching: Young Learners/By Caroline T. Linse; David Nunan, Series Editor. (New York: McGraw-Hill, 2005).

${ }^{15}$ Harmer, How to Teach English.

16 Nguyen Ngoc Nhat Minh, "Recording Technique: Possible Applications In Teaching And Learning Speaking Skills For EFL Learners," Journal of Science 70, no. 1 (2012), https://citeseerx.ist.psu.edu/viewdoc/download?doi=10.1.1.1037.6848\&rep=rep1\&type=pdf.

17 Tolga Erdogan and Irfan Yurdabakan, "Secondary School Students' Opinions On Portfolio Assessment In EFL," International Journal on New Trends in Education and Their Implications 2, no. 3 (2011): 63-72, http://www.ijonte.org/FileUpload/ks63207/File/ijonte.2011.3.pdf\#page=75.

${ }^{18}$ Elena Frolikova, "Reflection-Based Methodology of Developing Speaking Skills," Journal of the European Teacher Education Network 9 (2014): 102-12, https://etenjournal.com/2020/02/08/reflectionbased-methodology-of-developing-speaking-skills/. 
awareness within the constraints of their EFL contexts ${ }^{19}$. However, the problems listed above cause students' speaking skills to be relatively low. This condition happens at the university level in the rural area where they experience difficulties expressing their thoughts, feelings, and ideas in communication using the target language, English. Although they were in the fifth semester, many still felt insecure with their English competence. Grammatical mistakes such as deciding whether to use past or present tense were a constant source of anxiety. Therefore, they were not confident when delivering their speech ${ }^{20}$.

For example, there was a study carried out by Jasmadi titled "The Use of board game media in teaching speaking." The result showed that the use of board game media in teaching speaking has many positive effects on the students, such as: becoming more motivated to learn and skillful, because their learning interest increased, had an easy understanding of the material, was given opportunities to obtain a fair turn in practicing the material and were able to eliminate boredom while learning. Furthermore, they were encouraged to entertain new ideas, facilitate their remembrance and practice the material in their daily life. In addition, they learned enthusiastically during the period of teachinglearning activities which prompted them to show a positive attitude toward the implementation of board game media ${ }^{21}$.

Suryani, Aida, and Rosa carried out the second study, Rusdi Noor, titled Using A Board Game "Snake And Ladder" in teaching Speaking at Junior High School". The result showed that board game is a good media for developing students' speaking skills. Therefore the implementation of the board game was very useful and applicable in speaking class. This fact happened because it will make the students more creative in expressing their idea. Besides that, they will easily identify an idea in the picture. The board game also assists teachers and students in presenting the material effectively ${ }^{22}$.

19 Aleksandra Wach, "Promoting Pre-Service Teachers' Reflections Through A Cross-Cultural Keypal Project," Language Learning \& Technology 19, no. 1 (2015): 34-45, https://scholarspace.manoa.hawaii.edu/bitstream/10125/44397/19_01_action2.pdf.

${ }^{20}$ Nur Hayati, "Empowering Non-Native English Speaking Teachers Through Critical Pedagogy," TEFLIN Journal 21, no. 1 (August 29, 2015): 78-89, https://doi.org/10.15639/teflinjournal.v21i1/78-89.

${ }^{21}$ M. Arief Syakur, "The Use Of Board Game In Teaching Speaking To Young Learners," English Education:Journal of English Teaching and Research 5, no. 2 (October 29, 2020): 149-55, https://doi.org/10.29407/jetar.v5i2.14633.

${ }^{22}$ Aida Suryani and Rusdi Noor Rosa, "Using A Board Game 'Snake And Ladder' In Teaching Speaking At Junior High School,” Journal of English Language Teaching 2, no. 2 (March 1, 2014): 16-24, https://doi.org/10.24036/jelt.v2i2.3701. 
Based on the problems above and the previous studies, the author takes the initiative to carry out the study through developing the "Beberan" game board as an innovative media to improve students' speaking skills of pre-service teacher Islamic elementary education. This study is expected to answer how to develop a "Beberan" game board as an innovative medium. Therefore, it aimed to develop a "Beberan" game board to be a practical, easy-to-use, and effective media in improving students' speaking ability. This topic was selected to contribute to teaching speaking, especially in developing the "Beberan" game board as an innovative medium. By developing the "Beberan" game board, it is expected that teaching speaking for students of pre-service teacher Islamic elementary education should be easy, their interest spurred, can use their speaking ability and apply what they have studied when practicing at Islamic elementary school.

Many teachers are becoming obsolete during their lessons due to the limitation of the media and their experiments, especially in teaching speaking. Therefore, developing and applying the" Beberan" Game board as the main media is expected to engage and activate the students to participate more in the lesson. Engaging and activating the students are two important elements in teaching speaking. With proper engagement, participating in the study and activation stages are likely to be far more pronounced. Also, the benefit obtained from these will be considerably greater ${ }^{23}$. In addition, this topic has not been properly discussed in previous studies, especially in developing the media. Therefore, the author tries to develop the "Beberan" Game board as an innovative media to be a practical, effective and efficient media that is suitable for use in improving students' speaking skills, especially in English foreign language context.

\section{RESEARCH METHODS}

The research and development (R \& D) method were implemented, to develop board game as an interactive media in teaching speaking. Gall stated that educational $\mathrm{R}$ $\&$ D is a process used to develop and validate the educational product ${ }^{24}$. Meanwhile, Sugiyono stated that this method is used to produce a certain product and evaluate its

${ }^{23}$ Harmer, How to Teach English.

${ }^{24}$ Joyce P. Gall, Meredith D. Gall, and Walter R. Borg, Applying Educational Research: A Practical Guide (New York: Longman Publishing Group, 1999), 624. 
effectiveness $^{25}$. Figure 1 shows that the ten flows of R \& D proposed by Borg and Gall and Sugiyono were reduced and combined into seven steps.

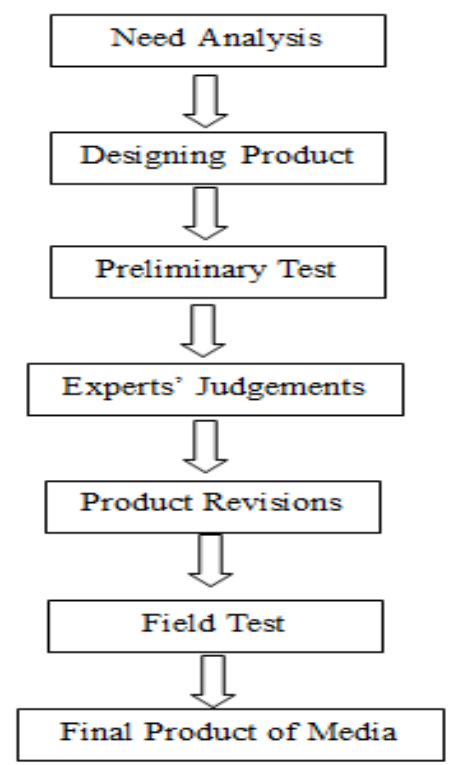

Figure 1

Steps Of Research And Development

This study was carried out in February-July 2019 and took place in Al-Anwar Islamic College in Rembang, Central Java, Indonesia. The subjects were 30 students of the fifth grade of Study Program Islamic Elementary Education, consisting of 8 (eight) males and 22 (twenty-two) females. Furthermore, to acquire sufficient data, the researcher used observation, interview, and test as the instruments. Firstly was an observation, which was a way of obtaining information by observing and making notes systematically about the observed phenomena. This activity had been carried out to obtain information about the problems that the lecturers and the students faced, especially in speaking classes. In this study, the researcher acted as a subject observer that watched, observed, and noted down the previous condition of the students in the classroom. Secondly was an interview, which was carried out by distributing a list of questions to discover particular information about the students and had been put back after the respondent's answer.

Thirdly was the test, which comprised pre-test and post-test. It comprises a series of questions or exercises and other tools to measure skills, abilities, knowledge, 297.

${ }^{25}$ Sugiyono, Metode Penelitian Kuantitatif Kualitatif Dan R\&D (Bandung: CV. Alfabeta, 2008), 
intelligence, or talents possessed by individuals or groups ${ }^{26}$. The pre-test was given to the students to examine their speaking skills before using the "Beberan" game board as an innovative learning media. Meanwhile, a post-test was given to determine whether the students' speaking improved or not.

\section{RESULT AND DISCUSSION}

This study was carried out by implementing the steps of the research and development method. The First step was about need analysis which was carried out to determine the need of both students and English lecturers in teaching speaking. In carrying out this activity, the researcher asked some lecturers about their opinion in speaking class, especially for students of the fifth grade of Islamic elementary education at Al-Anwar Islamic college and how they expected the environment to be in the speaking class, giving their experience before being a pre-service teacher at Islamic elementary school. This need analysis enabled the researcher to discover the answer to the question based on the interview given to the lecturers.

There were three results of the interview. Firstly, the lecturers wanted to change the methods used in teaching speaking. Secondly, the lecturers suggested changing the strategies in teaching speaking, and finally, the lecturers wanted to develop and make a new media. Table 1 shows the result of the interview.

Table 1

Result of Interview

\begin{tabular}{ccc}
\hline No & Name & Results \\
\hline 1 & Lecturer 1 & Changing the methods used in teaching speaking \\
\hline 2 & Lecturer 2 & Changing the strategies used in teaching speaking \\
\hline 3 & Lecturer 3 & Making a media, design a new media, develop media. \\
\hline
\end{tabular}

Based on the discussion with the other lecturers, the researcher took note of the suggestions made by the lecturers and decided to take the initiative to develop a media centered on the "Beberan" game board" and designed in a small shape. Figure 2 shows the shape of the "Beberan" game board" printed $50 \mathrm{~cm}$ X $50 \mathrm{~cm}$. 150.

${ }^{26}$ Suharsimi Arikunto, Research Procedure A Practical Approach (Jakarta: Rineka Cipta, 2010), 


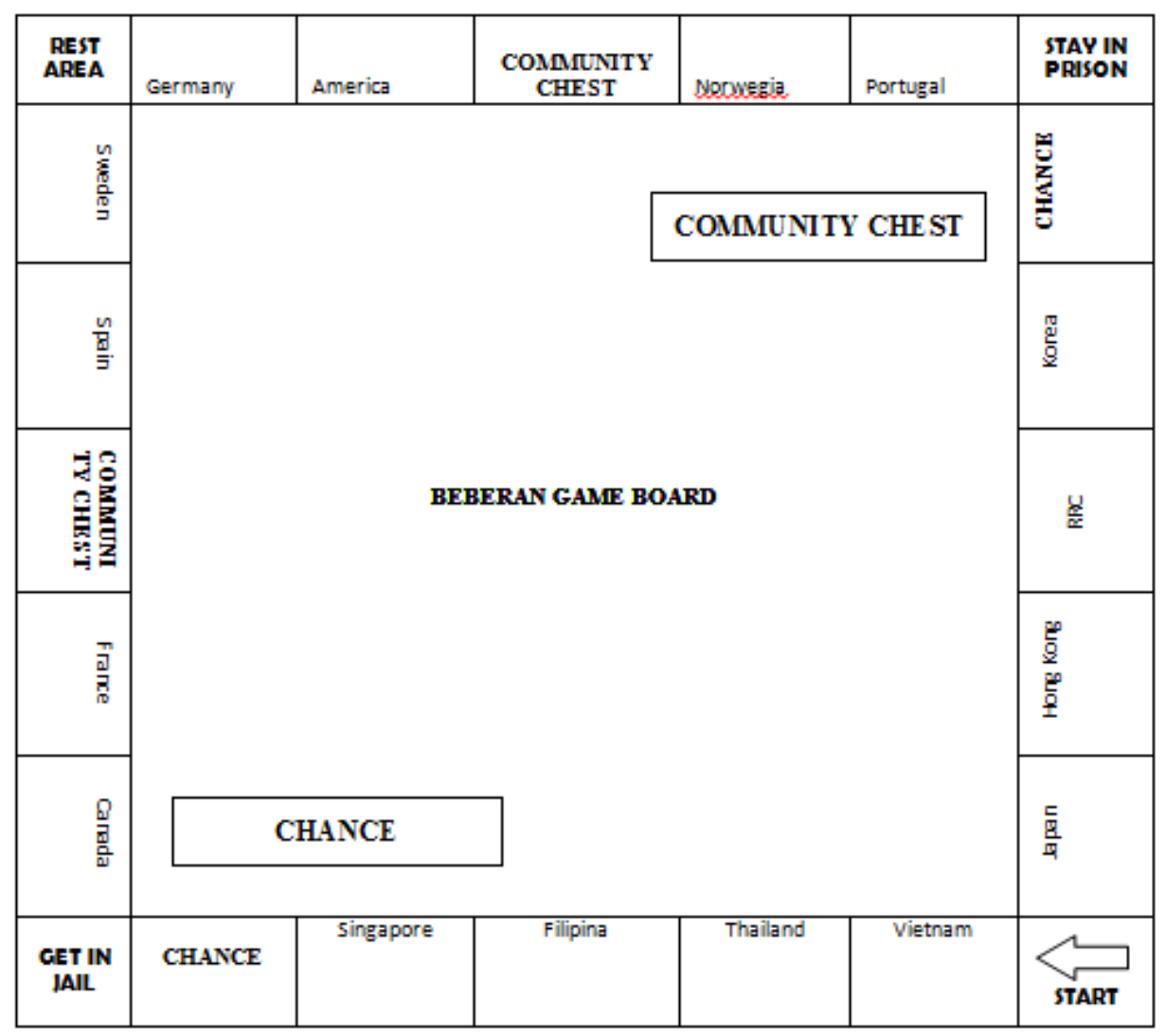

Figure 2

The shape of the "Beberan" game board" printed $50 \mathrm{~cm} \mathrm{X} 50 \mathrm{~cm}$

The next step was designing the product. This step involved two stages, namely developing the primary product, called the first product (as shown in Figure 2), and the preliminary test of the product carried out on small scales of students. The test was given by using the small shape of the "Beberan" game board. Based on the data acquired from the result of the interview carried out on a small scale of students, it was observed that the students showed no interest in joining the game. However, eight (8) students joined but later stated that it was not interesting. This finding happened because the media was small, which made running the game less enjoyable.

Furthermore, the researcher observed the implementation of the primary product, which entailed a series of steps on a limited basis. These steps include: first, performing initial field testing of the product design; second, limitation, both of the substance and the design of the parties involved; third, the initial field test repeatedly performed to obtain a feasible design both substance and methodology. 
After carrying out a need analysis, designing the product, and a preliminary test, the next step was Experts' judgments. This step was carried out immediately after the preliminary test, while validity from the expert was carried out to test the primary product. This step would assist the researcher in mapping the development of the product. In carrying out this step, two experts were instructed to analyze the product. The analysis process involved implementing this product in teaching speaking and media components such as animations, form, and images. Table 2 shows suggestions from expert's judgments. After analyzing the product, suggestions were sort from the experts in other to develop the product.

Table 2

Suggestions from Experts Judgments

No. $\quad$ Suggestions from Expert Judgments 1 and 2

1 Change the Animations on the game board

2 Change the color of the game board

3 Add the Images on the board

$4 \quad$ Change the shape into a wider shape

Furthermore, after the preliminary test and experts' validation, product revisions were carried out, where the researcher analyzed and revised the product based on the result of the preliminary field test, including components of the board game.

The next step was a field test which was carried out to test the product extensively. This test involves a series of other steps, which include: first, to test the effectiveness of product design; second, to test the effectiveness of the design generally using experimental techniques models; third, to obtain field result of the effective design, both in terms of substance and methodology. The final media, which had been developed and modified with the result of the main field test, yielded the final product of the "Beberan" game board as media in teaching speaking.

The fixed developed media was ready to be introduced and used by the public, particularly in teaching speaking, using the "Beberan" game board that the researcher had earlier developed through the steps listed in research and development. Figure 3 shows the shape of "beberan" game board printed $2 \mathrm{~m} \times 2 \mathrm{~m}$. 


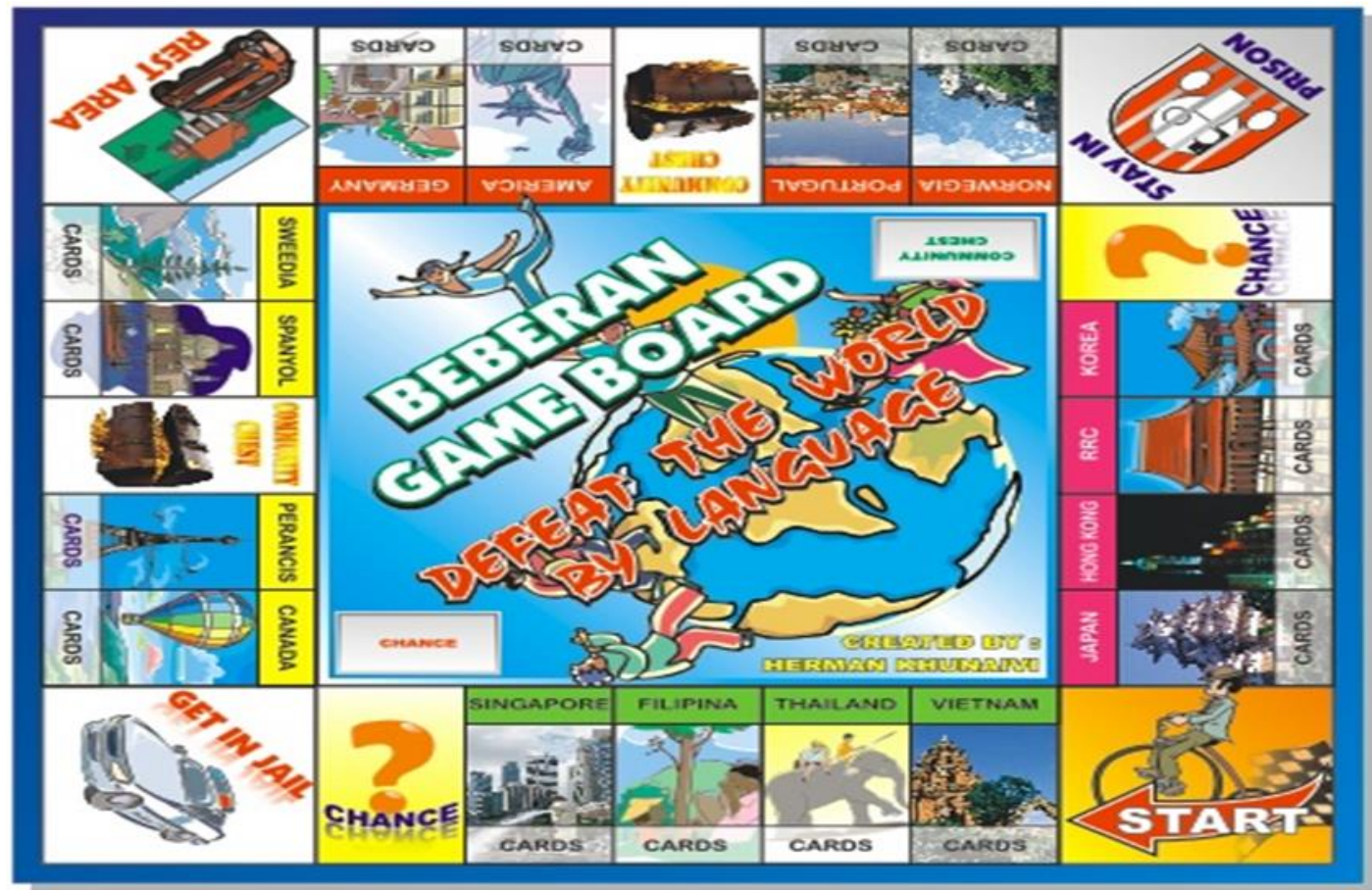

Figure 3

The shape of the "Beberan" game board Printed $2 \mathrm{~m} \times 2 \mathrm{~m}$

The result of the pre-test previously given to the students by the researcher was 67.86667. Table 3 shows the result of the pre-test.

Table 3

Result of Pre-test

\begin{tabular}{ccc}
\hline \multicolumn{3}{c}{ Results of pre-test } \\
\hline Total of students & Sum & Average \\
\hline 30 students & 2036 & 67.867 \\
\hline
\end{tabular}

Table 3 showed that a low performance was obtained using the "Beberan" game board printed in small shape (first product or primary product). This finding prompted the researcher to consult the experts' judgment, asking for suggestions in developing this media. Finally, the researcher developed a new design of the "Beberan" game board based on the suggestions of experts' judgment and printed the final product in a big shape full of pictures and designs. Meanwhile, the result of the post-test carried out on the students to know whether their ability in speaking improved or not was 72.133 (as shown in table 5 below). Table 4 shows the result of the post-test. 
Table 4

Result of Post-test

\begin{tabular}{clc}
\hline \multicolumn{2}{c}{ Results of post-test } \\
\hline Total of students & Sum & Average \\
\hline 30 students & 2164 & 72.133 \\
\hline
\end{tabular}

Table 4 showed that there was an improvement in their speaking skill from 67.867 to 72.133. Furthermore, according to the results of the developing "Beberan" game board, it could be stated that a great improvement has been observed since its implementation in teaching speaking to the fifth-grade students of Islamic Elementary education. The result showed that the students' speaking skills greatly improved through the joint effort of the activity of the "Beberan" game board.

This study was following previous studies carried out by Arifuddin Hamra and Eny Syatriana on developing a model of teaching reading comprehension for EFL students. It showed that the learning condition, teaching and learning process, reading comprehension, instructional reading materials, and teachers' teaching performance were well established according to the teachers and students. This interactive model improved the students' reading comprehension significantly; therefore, it is an alternative model of teaching reading for EFL students. ${ }^{27}$ In addition, the result of the needs survey on the study carried out by Sismiati, and Mohammad Adnan Latief on developing instructional materials on English oral communication for nursing schools showed that English communication skill of the students in nursing school speaking classes is not well developed. Consequently, the speaking instructional materials used in the classes need to be advanced. The product of this study is a communicative syllabus and a handbook of speaking for nursing. This product was developed by using Yalden's model (LPD) modified for the study's practical aim. ${ }^{28}$

Furthermore, the study carried out by Fitriah showed that teachers are aware of the importance of technology in creativity. Technology aids them to explore their creativity and encourages learners' creativity in a way that aids transfer their creativity

${ }^{27}$ Arifuddin Hamra and Eny Syatriana, "Developing A Model Of Teaching Reading Comprehension For Efl Students," TEFLIN Journal 21, no. 1 (August 29, 2015): 27-40, https://doi.org/10.15639/teflinjournal.v21i1/27-40.

${ }^{28}$ Sismiati Sismiati and Mohammad Adnan Latief, "Developing Instructional Materials On English Oral Communication For Nursing Schools," TEFLIN Journal 23, no. 1 (January 1, 2012): 44-59, https://doi.org/10.15639/teflinjournal.v23i1/44-59. 
into reality, makes the activities more authentic, and provides teaching materials on various topics. ${ }^{29}$ Therefore, it is recommended that language teachers give more importance to strategic task planning and the instruction of speaking strategies. ${ }^{30}$

These previous studies listed above had focused on other fields of study. Consequently, by carrying out this study, the researcher discovered a lot of new things. Developing the "Beberan" game board as an innovative media was one of the media that greatly changed the way teachers taught speaking by engaging the students and providing them with more opportunities while running the "Beberan" game board. Therefore, improving the ability of the students to explore their ideas and opinion, including their use of English.

\section{CONCLUSION}

This research found that the development of the "Beberan" game board as an innovative media greatly improved students' speaking skills of the teacher trainees' students. It is observed from the pre-test and post-test scores, which increased from 67.867 to 72.133 that there was an improvement after using the "Beberan" game board developed by using the steps of research and development. Although the subjects of this study were fifth-grade level students, their speaking ability was still at beginner level. However, it was expected that after this study, the speaking skill of the teacher trainees' students improved. This skill would be of great use when teaching their students, especially in the English language for elementary students' level that teaches English to young learners, especially in teaching speaking.

The development of the "Beberan" game board was expected can produce simple media in teaching and learning processes for students at a lower level. This media improves the students' involvement and participation in speaking because they interact with other students and communicate using the target language, English. It was concluded that developing Beberan" game board as media was easy to use. Furthermore, it made

${ }^{29}$ Fitriah Fitriah, "The Role Of Technology In Teachers Creativity Development In English Teaching Practices," TEFLIN Journal 29, no. 2 (July 25, 2018): 177-93, https://doi.org/10.15639/teflinjournal.v29i2/177-193.

${ }^{30}$ Zahra Moradi and Seyed Hassan Talebi, "The Effect of Pre-Speaking Strategies Instruction in Strategic Planning on Iranian EFL Students' Awareness as Well as Students' Fluency and Lexical Resources in Speaking," Procedia - Social and Behavioral Sciences, Proceedings of the International Conference on Current Trends in ELT, 98 (May 6, 2014): 1224-31, https://doi.org/10.1016/j.sbspro.2014.03.537. 
easy understanding teaching speaking easy and aided its application as an efficient media to improve students' speaking ability. It is used not only in teaching speaking but also in teaching vocabularies, teaching reading, and other skills in teaching English.

I realized that there are still deficiencies and weaknesses of this study because of the limitation of the researcher. Therefore, new media regarded as the best media should be developed in the teaching and learning process. This media would be one of the tools that will ensure teaching and learning run smoothly and easily. Furthermore, it will be of great benefit to other studies to carry out this study to combine, design, and develop better media to be used in teaching English, especially in a foreign language context.

\section{ACKNOWLEDGMENTS}

The author would like to express his sincere thanks to Dr. KH. Abdul Ghofur, M.A as the chairman of Islamic Al-Anwar Islamic College who gave the author opportunity and support to conduct this study at Islamic elementary education study program. Secondly, the author would like to express gratitude and appreciation to Mr. Yadhi Nur Amin, M.Pd, Mr. Bahrudin, M.Pd, Mrs. Syarifatul Fitri H, M.Pd and who patiently gave the author helpful effort and beneficial comments for this journal article progress.

\section{DECLARATION OF CONFLICTING INTERESTS}

The author declared that there are no potential conflicts of interest with respect to the research, authorship, and/or publication of this article.

\section{FUNDING}

This research was fully funded individually by the author.

\section{ORCID iD}

Herman Khunaivi

\section{REFERENCES}

Abdullah, Mohd. Yusof, Noor Rahamah Abu Bakar, and Maizatul Haizan Mahbob. "Student's Participation In Classroom:What Motivates Them To Speak Up?" Procedia - Social and Behavioral Sciences, The World Conference on Design, Arts and Education (DAE-2012), May 1-3 2012, Antalya, Turkey, 51 (January 1, 2012): 516-22. https://doi.org/10.1016/j.sbspro.2012.08.199.

Abebe, Dawit Tesfaye, and D Deneke. "Causes Of Students' Limited Participation In EFL Classroom: Ethiopian Public Universities In Focus.” International Journal 
of Educational Research and Technology 6, no. 1 (2015): 74-89. http://soeagra.com/ijert/ijertmarch2015/8.pdf.

Arikunto, Suharsimi. Research Procedure A Practical Approach. Jakarta: Rineka Cipta, 2010, 152.

Bahadorfar, Maryam, and Reza Omidvar. "Technology In Teaching Speaking Skill. Research Scholar, Department of Linguistics, KIKS, University of Mysore, Mysore (India)." Acme International Journal of Multidisciplinary Research 2 (2014). https://www.researchgate.net/publication/315790125_TECHNOLOGY_IN_TE ACHING_SPEAKING_SKILL.

Caicedo, Jefferson. "Teacher Activities and Adolescent Students' Participation in a Colombian EFL Classroom." Profile Issues in Teachers' Professional Development 17, no. 2 (July 2015): 149-63. https://doi.org/10.15446/profile.v17n2.48091.

Erdogan, Tolga, and Irfan Yurdabakan. "Secondary School Students' Opinions On Portfolio Assessment In EFL." International Journal on New Trends in Education and Their Implications 2, no. 3 (2011): 63-72. http://www.ijonte.org/FileUpload/ks63207/File/ijonte.2011.3.pdf\#page=75.

Fitriah, Fitriah. "The Role Of Technology In Teachers Creativity Development In English Teaching Practices." TEFLIN Journal 29, no. 2 (July 25, 2018): 177-93. https://doi.org/10.15639/teflinjournal.v29i2/177-193.

Frolikova, Elena. "Reflection-Based Methodology of Developing Speaking Skills." Journal of the European Teacher Education Network 9 (2014): 102-12. https://etenjournal.com/2020/02/08/reflection-based-methodology-ofdeveloping-speaking-skills/.

Gall, Joyce P., Meredith D. Gall, and Walter R. Borg. Applying Educational Research: A Practical Guide. New York: Longman Publishing Group, 1999.

Hamra, Arifuddin, and Eny Syatriana. "Developing A Model Of Teaching Reading Comprehension For Efl Students." TEFLIN Journal 21, no. 1 (August 29, 2015): 27-40. https://doi.org/10.15639/teflinjournal.v21i1/27-40.

Harmer, Jeremy. How to Teach English. Oxford: Pearson Education Limited, 2007.

Hayati, Nur. "Empowering Non-Native English Speaking Teachers Through Critical Pedagogy." TEFLIN Journal 21, no. 1 (August 29, 2015): 78-89. https://doi.org/10.15639/teflinjournal.v21i1/78-89.

Koşar, G, and Hasan Bedir. "Strategies-Based Instruction: A Means Of Improving Adult EFL Learners' Speaking Skills.” International Journal of Language Academy 2, no. 3 (2014): 12-26. http://oaji.net/articles/2014/505-1411382239.pdf.

Kunandar. Guru Profesional Implementasi Kurikulum Tingkat Satuan Pendidikan (KTSP) Dan Sukses Dalam Sertifikasi Guru. Jakarta: Rajawali Pers, 2014.

Linse, Caroline. Practical English Language Teaching: Young Learners/By Caroline T. Linse; David Nunan, Series Editor. New York: McGraw-Hill, 2005. 
Mei, Leong Lai, and Ahmadi Seyedeh Masoumeh. "An Analysis of Factors Influencing Learners' English Speaking Skill” 2, no. 1 (January 1, 2017): 34-41. https://www.sid.ir/en/journal/ViewPaper.aspx?ID=520992.

Minh, Nguyen Ngoc Nhat. "Recording Technique: Possible Applications In Teaching And Learning Speaking Skills For EFL Learners." Journal of Science 70, no. 1 (2012).

https://citeseerx.ist.psu.edu/viewdoc/download?doi=10.1.1.1037.6848\&rep=rep1 \&type $=$ pdf.

Ministry of Education. "'Special Guidelines Competency-Based Curriculum Development Syllabus English' (Curriculum Development Syllabus English).” Ministry of Education of Indonesia, 2004.

Moradi, Zahra, and Seyed Hassan Talebi. "The Effect of Pre-Speaking Strategies Instruction in Strategic Planning on Iranian EFL Students' Awareness as Well as Students' Fluency and Lexical Resources in Speaking." Procedia - Social and Behavioral Sciences, Proceedings of the International Conference on Current Trends in ELT, 98 (May 6, 2014): 1224-31. https://doi.org/10.1016/j.sbspro.2014.03.537.

Richards, Jack Croft. Teaching Listening And Speaking. Cambridge: Cambridge University Press, 2008.

Sismiati, Sismiati, and Mohammad Adnan Latief. "Developing Instructional Materials On English Oral Communication For Nursing Schools." TEFLIN Journal 23, no. 1 (January 1, 2012): 44-59. https://doi.org/10.15639/teflinjournal.v23i1/44-59.

Sugiyono. Metode Penelitian Kuantitatif Kualitatif Dan R\&D. Bandung: CV. Alfabeta, 2008.

Suryani, Aida, and Rusdi Noor Rosa. "Using A Board Game 'Snake And Ladder' In Teaching Speaking At Junior High School." Journal of English Language Teaching 2, no. 2 (March 1, 2014): 16-24. https://doi.org/10.24036/jelt.v2i2.3701.

Syakur, M. Arief. “The Use Of Board Game In Teaching Speaking To Young Learners." English Education:Journal of English Teaching and Research 5, no. 2 (October 29, 2020): 149-55. https://doi.org/10.29407/jetar.v5i2.14633.

Theriault, Jennifer C. "Exploring College Students' Classroom Participation: A Case Study of A Developmental Literacy Classroom." Journal of College Reading and Learning 49, no. 3 (September 2, 2019): 206-22. https://doi.org/10.1080/10790195.2019.1638219.

Wach, Aleksandra. "Promoting Pre-Service Teachers' Reflections Through A CrossCultural Keypal Project.” Language Learning \& Technology 19, no. 1 (2015): 3445. https://scholarspace.manoa.hawaii.edu/bitstream/10125/44397/19_01_action2.p df. 